Konrad Wiltosiński

ORCID: 0000-0001-8388-8217

Uniwersytet Śląski

https://doi.org/10.19195/1733-5779.30.12

\title{
Prawidłowość wdrożenia dyrektywy 2008/48/WE z dnia 23 kwietnia 2008 roku w zakresie krajowej regulacji limitu pozaodsetkowych kosztów kredytowych — prawne aspekty problemu
}

\section{JEL Classification: K12, K15}

Słowa kluczowe: ochrona konsumenta, zbliżenie ustawodawstw, maksymalne pozaodsetkowe koszty kredytu, pożyczka konsumencka

Keywords: consumer protection, approximation of laws, maximum non-interest credit costs, consumer loan

Abstrakt: Niniejszy artykuł podejmuje analizę wprowadzonego niedawno do polskiego ustawodawstwa art. 36a-36d ustawy o kredycie konsumenckim. Autor broni zapatrywania, że przyjęte przez krajowego ustawodawcę rozwiązania prawne są błędną próbą implementowania do krajowego porządku prawnego dyrektywy 2008/48/WE, albowiem zezwalają na zaliczenie do kosztów związanych z umową o kredyt ponoszonych przez konsumenta również kosztów działalności gospodarczej prowadzonej przez przedsiębiorcę. Ponadto opracowanie ma na celu syntetyczne przedstawienie głównych nurtów reprezentowanych w doktrynie i judykaturze w omawianej kwestii.

\section{Correctness of implementation of Directive 2008/48/EC of 23 April 2008 as to national regulations of limits of non-interest credit costs - legal aspects}

\begin{abstract}
The following article attempts to analyze Articles 36a-36d of the Act on Consumer Credits, recently introduced into Polish legislation. The author of the article defends the view that legal regulations, as adopted by the national legislator, have been a false attempt to implement Directive 2008/48/EC in the national legal order, as they allow for a classification of entrepreneurs' business overhead costs as costs related to credit agreements to be borne by consumers. Furthermore,
\end{abstract}

\footnotetext{
* Opiekun naukowy (Scientific Tutor ) - prof. dr hab. Wojciech Klyta
} 
the following paper aims at presenting, in a synthetic way, the main trends represented in the case-related doctrine and judicial decisions.

\section{Uwagi wstępne}

Asumpt do napisania niniejszego artykułu dało pytanie prejudycjalne z dnia 31 stycznia 2019 roku (I C 859/18), skierowane do Trybunału Sprawiedliwości Unii Europejskiej w Luksemburgu (dalej: TSUE) przez Sąd Rejonowy w Opatowie ${ }^{1}$, dotykające problematyki oceny rozwiązań ustawowych przyjętych przez krajowego legislatora w kwestii limitu pozaodsetkowych kosztów kredytowych, zawartych w umowie kredytu konsumenckiego, w tym art. 36a ustawy o kredycie konsumenckim ${ }^{2}$, pod kątem zgodności zawartych w nim unormowań z dyrektywą 2008/48/WE z dnia 23 kwietnia 2008 roku w sprawie umów o kredyt konsumencki oraz uchylająca dyrektywę Rady 87/102/EWG ${ }^{3}$. Wątpliwości sądu odsyłającego dotyczyły też prawnych aspektów sądowej dopuszczalności badania abuzywności postanowień umownych w zakresie limitów pozakodeksowych kosztów zawartych W umowie kredytu konsumenckiego ${ }^{4}$. Artykuł ma na celu przybliżenie czytelnikowi problematyki zawartej w skierowanym do TSUE pytaniu prejudycjalnym, albowiem bez wątpienia postawione przed TSUE wątpliwości interpretacyjne są niezwykle istotne $\mathrm{z}$ punktu widzenia transparencji funkcjonowania $\mathrm{w}$ krajowym porządku prawnym relacji prawnych występujących na płaszczyźnie przedsiębiorca-konsument.

\section{Tło faktyczne sprawy}

Strona powodowa zawarła z pozwaną umowę pożyczki krótkoterminowej, na mocy której wypłacono pozwanej środki finansowe z obowiązkiem ich zwrotu $\mathrm{w}$ terminach zastrzeżonych $\mathrm{w}$ harmonogramie spłat. Umowa została zabezpieczona wekslem in blanco. W związku z brakiem spłat umówionych rat pożyczki umowa została wypowiedziana, co skutkowało wystąpieniem przez powoda na

1 Odesłanie prejudycjalne - Postanowienie Sądu Rejonowego w Opatowie z dnia 31 stycznia 2019 roku sygn. akt I C 859/18 (dostępne na portalu orzeczeń), Sprawa zarejestrowana przed TSUE pod sygn. C-252/19 Dz.U.UE.C.2019.280.18/1 z dnia 19 sierpnia 2019 roku.

2 Ustawa z dnia 12 maja 2011 roku o kredycie konsumenckim, Dz.U. 2011 Nr 126, poz. 715 z późn. zm.

3 Dyrektywa 2008/48/WE z dnia 23 kwietnia 2008 roku w sprawie umów o kredyt konsumencki oraz uchylająca dyrektywę Rady 87/102/EWG, Dz.Urz.UE.L 2008 nr 133, ze zm.

${ }^{4}$ Równie interesujące pytania prejudycjalne na płaszczyźnie dopuszczalności sądowego badania abuzywności pozakodeksowych kosztów kredytowych zawarł Sąd Rejonowy w Siemianowicach Śląskich w postanowieniu z dnia 9 listopada 2018 roku sygn. akt I C 2923/17, I C-779/18 Dz.U.UE.C.2019.164.4 z dnia 13 maja 2019 roku oraz Sąd Rejonowy Szczecin — Prawobrzeże i Zachód w Szczecinie w postanowieniu z dnia 31 stycznia 2019 r. I C 84-/19 Dz.U.UE.C.2019.164.17 z dnia 13 maja 2019 roku, które z uwagi na ograniczone ramy niniejszego artykułu nie zostały w niniejszym opracowaniu zaprezentowane. 
drogę sądową. W pozwie skierowanym do sądu odsyłającego powód dochodził od strony pozwanej będącej konsumentem poza kapitałem pożyczki również kosztów udzielonej pożyczki (wynagrodzenie prowizyjne, opłata przygotowawcza, opłata za usługę), łącznie 10764,00 zł (około 2474 euro). Symptomatyczne z punktu zainteresowania niniejszego artykułu jest to, że wysokość tych kosztów nie była negocjowana przez strony i została ustalona arbitralnie przez pożyczkodawcę ryczałtowo, przy zastosowaniu wzoru przewidzianego $\mathrm{w}$ art. 36a ustawy z dnia 12 maja 2011 roku o kredycie konsumenckim ${ }^{5}$ i w granicach przewidzianego w rzeczonym przepisie limitu pozakodeksowych kosztów kredytu. W omawianej sprawie strona powodowa, uzasadniając żądanie w zakresie dochodzonych dodatkowych kosztów, nie wyjaśniła sposobu ustalania pozakodeksowych kosztów, w szczególności nie zilustrowała zgodnie z reżimem art. 6 kodeksu cywilnego (dalej: k.c. $)^{6}$, jakie to konkretne czynności czy poniesione przez przedsiębiorcę wydatki miałyby pokrywać dochodzone w pozwie dodatkowe koszty kredytu. Równie znamienne w relacjonowanej sprawie jest to, że strona powodowa, argumentując zasadność obciążenia strony pozwanej kosztami, odwołała się do uzasadnienia projektu ustawodawcy wprowadzającego art. 36a do ustawy o kredycie konsumenckim ${ }^{7}$, w którym zawarto ekonomiczne uzasadnienie pozaodsetkowych kosztów kredytu w jego maksymalnych wysokościach ${ }^{8}$ (to jest w granicach limitu $\mathrm{z}$ art. 36a ustawy o kredycie konsumenckim). Sąd meriti powzią jednakże wątpliwość natury interpretacyjnej, zwracając się do TSUE z pytaniem prejudycjalnym $\mathrm{w}$ celu oceny rozwiązań ustawowych przyjętych przez krajowego legislatora $\mathrm{w}$ art. 36a ustawy o kredycie konsumenckim pod kątem zgodności zawartych w nim unormowań z dyrektywami unijnymi, nakazującymi państwom członkowskim, a w dalszym etapie również sądom krajowym, szczególną ochronę konsumentów.

\section{Aktualne stanowisko judykatury wypracowane na polu sądowej dopuszczalności badania abuzywności limitów pozakodeksowych kosztów kredytowych}

Dorobek orzeczniczy jednoznacznie wskazuje, że omawiana materia nie jest odosobniona, a samo orzecznictwo sądów w przedmiocie dopuszczalności badania

${ }^{5}$ Ustawa z dnia 12 maja 2011 roku o kredycie konsumenckim Dz.U. 2011 Nr 126, poz. 715 z poźn. zm.

${ }^{6}$ Ustawa z dnia 23 kwietnia 1964 roku - Kodeks cywilny Dz.U. 1964 Nr 16, poz. 93, tekst jedn. Dz.U. z 2019 poz. 1145.

7 Ustawa z dnia 12 maja 2011 roku o kredycie konsumenckim, Dz.U. 2011 Nr 126, poz. 715 z poźn. zm.

8 Stan faktyczny ograniczono do wskazania kluczowych okoliczności faktycznych sprawy zawisłej przed Sądem Rejonowym w Opatowie, celowo pomijając okoliczności dotyczące wysokości konkretnych wierzytelności składających się na żądanie pozwu itp., które to informacje zdaniem autora nie definiują istoty problemu leżącego w kręgu zainteresowania przedmiotu niniejszego artykułu. 
abuzywności pozaodsetkowych kosztów kredytowych jest dalece niejednolite 9 . $\mathrm{W}$ praktyce sądów prym wiodą dwie skrajnie odmienne linie orzecznicze ${ }^{10}$. Pierwsza jest zwolennikiem wyłączenia spod możliwości badania abuzywności pozaodsetkowych kosztów umowy kredytowej ${ }^{11}$. Główne jej założenia sprowadzają się do postulatu zbieżnego ze stanowiskiem prezentowanym przez stronę powodową $\mathrm{w}$ analizowanych sprawach, a mianowicie, że skoro ustawodawca $\mathrm{w}$ art. 36a ustawy o kredycie konsumenckim wprowadził do porządku prawnego regulację limitu pozaodsetkowych kosztów kredytowych, to - o ile nie przekraczają one tego limitu — ich badanie przez sąd w tej materii jest wykluczone (Lex iubeat non disputat $)^{12}$. Sądy orzekające w tym kanonie argumentacyjnym uznają bowiem, że racjonalny ustawodawca należycie wyważył i zmiarkował interesy stron stosunku kredytowego, co znajduje definitywny przejaw w ustanowionej przez niego regulacji ustawowej ${ }^{13}$.

Z kolei drugi z wymienionych poglądów — całkowicie odmienny — stoi na stanowisku, że wprowadzenie limitu pozaodsetkowych kosztów kredytu nie oznacza ex definitione braku uprawnienia po stronie sądu do oceny postanowień umownych przez pryzmat ich abuzywności ${ }^{14}$. Zwolennicy tego nurtu kładą nacisk głównie na ograniczenia płynące z regulacji art. 385 (1) § 1 i następne k.c. (niedozwolone postanowienia umowne, klauzule abuzywne) ${ }^{15}$. To właśnie w duchu drugiej z wymienionych koncepcji oscylowały główne refleksje i założenia ideowe sądu odsyłającego.

9 M.T. Kamiński, Limit pozaodsetkowych kosztów w umowie kredytu konsumenckiego a dopuszczalność badania abuzywności postanowień umownych w tym zakresie, Warszawa 2018.

${ }^{10}$ Wspomnieć należy również o trzecim, umiarkowanym nurcie wykoncypowanym przez orzecznictwo, który skłania się do odpowiedniego zrelatywizowania wysokości pozaodsetkowych kosztów kredytu konsumenckiego do faktycznego czasu trwania umowy; zob. ibidem, i powołany tam wyrok Sądu Okręgowego w Sieradzu z 29 listopada 2017 roku, I Ca 437/17, LEX nr 2421425.

11 M.T. Kamiński, op. cit., i powołane tam orzecznictwo.

12 K. Burczak, A. Dębiński, M. Jońca, Lacińskie sentencje i powiedzenia prawnicze, Warszawa 2018.

13 Por. np. uzasadnienie wyroku Sądu Okręgowego w Łodzi z dnia 27 kwietnia 2018 roku, III Ca 243/18, LEX nr 2544272.

14 M.T. Kamiński, op. cit., i powołane tam orzecznictwo. W doktrynie w podobnym tonie również T. Czech, Limit pozaodsetkowych kosztów kredytu, „Prawo Bankowe” 2016, nr 2: „Okoliczność, że obowiązuje limit pozaodsetkowych na podstawie art. 36a-36d (powołanej wyżej ustawy, nie wyłącza kontroli postanowień wzorca umowy, które odnoszą się do takich kosztów, pod kątem skuteczności ich inkorporacji do stosunku prawnego oraz pod względem ich abuzywności".

15 Por. np. wyrok Sądu Rejonowego w Kaliszu z dnia 16 kwietnia 2018 roku, I C 3975/17, LEX nr 2545262, i powołany tam wyrok II Ca 5/18 Sądu Okręgowego w Kaliszu (niepubl.). 


\section{Ramy prawne zawisłego przed TSUE problemu}

Źródłem inspiracji sądu odsyłającego do wystąpienia do TSUE z pytaniem prejudycjalnym była negatywna ocena krajowych rozwiązań ustawodawczych w zakresie wprowadzonej przez legislatora instytucji limitów pozaodsektowych kosztów kredytowych, zwłaszcza art. 36a, przez pryzmat dyrektyw unijnych odnoszących się do kwestii ochrony praw konsumenta, a konkretnie dyrektywy 2008/48/WE z dnia 23 kwietnia 2008 roku w sprawie umów o kredyt konsumencki oraz uchylająca dyrektywę Rady 87/102/EWG. Statuując swoje pytanie, sąd odsyłający zwrócił się do TSUE z następującą wątpliwością:

Czy przepisy ww. dyrektywy, zwłaszcza art. 3 pkt. g) i art. 22 ust.1 dyrektywy, należy interpretować w ten sposób, że przywołane przepisy stoją na przeszkodzie wprowadzeniu do porządku krajowego instytucji „,maksymalnych pozaodsetkowych kosztów kredytu” oraz matematycznego wzoru obliczenia wysokości tych kosztów przewidzianych w art. 5 pkt. 6a w zw. z art. 36a ustawy z 12 maja 2011 r. o kredycie konsumenckim (t.j. Dz.U.2018.993), które to rozwiązania prawne zezwalają na zaliczenie do kosztów związanych z umową o kredyt ponoszonych przez konsumenta (całkowitego kosztu kredytu) również kosztów działalności gospodarczej prowadzonej przez przedsiębiorcę?

W świetle tak zdefiniowanego przez sąd odsyłający pytania należy przyjąć, że jego materia w istocie nie dotyczy samej egzegezy pojęcia „pozakodeksowych kosztów kredytu", ale de facto sprowadza się do oceny przez Trybunał systemu środków ochrony konsumenta zawartego w znowelizowanej ustawie o kredycie konsumenckim pod kątem realizacji implementowanej do porządku krajowego dyrektywy 2008/48/WE. Przez swoje pytanie prejudycjalne sąd odsyłający de facto kontestuje przyjęte przez krajowego ustawodawcę rozwiązania prawne w zakresie wprowadzenia odrębnego i niezależnego pojęcia ,pozaodsetkowych kosztów kredytu", które zawiera możliwość obciążenia konsumenta kosztami związanymi z działalnością gospodarczą kredytodawcy. Sąd odsyłający oparł się przy tym na wyartykułowanej w dyrektywie ${ }^{16}$ expressis verbis zasadzie harmonizacji, która zawiera nie tylko nakaz zapewnienia wszystkim konsumentom we Wspólnocie wysokiego i równoważnego poziomu ochrony ich interesów i stworzenia prawdziwego rynku wewnętrznego, lecz także zakazuje państwom członkowskim w zakresie, $\mathrm{w}$ jakim dyrektywa zawiera zharmonizowane przepisy, utrzymywanie w swoim prawie krajowym i wprowadzanie do niego przepisów odbiegających od tych, które zostały ustanowione w dyrektywie. Samo wykroczenie poza dopuszczalne granice obciążenia konsumenta określone art. 3 pkt g dyrektywy było zdaniem sądu odsyłającego konsekwencją przyjętego przez ustawodawcę krajowego sposobu obliczania maksymalnej wysokości pozaodsetkowych kosztów kredytu, to jest przy zastosowaniu matematycznego wzoru przewidzianego w art. 36a u.k.k. Sąd odsyłający dostrzegł, że wzór ten został ustalony przy uwzględnieniu procentowych wskaźników

16 Art. 22 preambuły dyrektywy 2008/48/WE Parlamentu Europejskiego i Rady z dnia 23 kwietnia 2008 roku. 
kosztów operacyjnych, ponoszonych przez przedsiębiorców i przy założeniu, że wysokość maksymalnych pozaodsetkowych kosztów kredytu, obliczonych wedle tego wzoru, ma służyć pokryciu kosztów działalności gospodarczej kredytodawcy i zapewnić mu ekonomiczną opłacalność. Wskazał również, że co prawda dyrektywa 2008/48/WE przewiduje możliwość obciążenia konsumenta kosztami, jednak $\mathrm{z}$ art. 3 pkt g wynika, że konsument może zostać obciążony wyłącznie kosztami pozostającymi w związku z umową kredytową, do których koszty działalności gospodarczej nie należą. W tej sytuacji sąd odsyłający wywiódł, że wprowadzenie instytucji pozaodsetkowych kosztów kredytu było chybionym środkiem do realizacji celów przewidzianych dyrektywą, skoro konsekwencją obowiązywania tej instytucji jest możliwość zwiększenia obciążenia finansowego konsumenta poza granice wyznaczone przez zakreśloną dyrektywą definicję całkowitych kosztów kredytu, to jest kosztów związanych z umową kredytu.

\section{Geneza figury prawnej „maksymalnych pozaodsetkowych kosztów kredytu"}

Głównym celem wprowadzonej do krajowego porządku prawnego ustawy o kredycie konsumenckim (dalej: KredytKonsU), będącej konsekwencją implementacji do polskiego porządku prawnego dyrektywy 2008/48/WE Parlamentu Europejskiego i Rady z dnia 23 kwietnia 2008 roku w sprawie umów o kredyt konsumencki, było zwiększenie ochrony prawnej przysługującej konsumentom, którzy nie mając specjalistycznej wiedzy w zakresie rynku finansowego, przystępują do zawarcia umowy o kredyt konsumencki z bankami i innymi instytucjami kredytowymi, dysponującymi w tym zakresie nieporównywalnie większą wiedzą i doświadczeniem. Założeniem ustawy o kredycie konsumenckim było więc wprowadzenie w polskim systemie prawnym zharmonizowanych ram unijnych regulacji prawnych dotyczących funkcjonowania rynku finansowego ${ }^{17}$, mających na celu zwiększenie poziomu ochrony uzasadnionych interesów konsumentów, dokonujących czynności prawnych z różnymi instytucjami kredytowymi ${ }^{18}$. Jednocześnie implementowana dyrektywa 2008/48/WE wyrażała zasadę pełnej harmonizacji kierunkowej ${ }^{19}$.

17 Z. Ofiarski, Ustawa o kredycie konsumenckim, komentarz, Warszawa 2014, s. 23-26.

18 D. Sowińska-Kobelak, M. Gryber, Przewodnik po kredycie konsumenckim, 2018, s. 6. Założenia do ustawy o kredycie konsumenckim w związku z implementacją dyrektywy parlamentu Europejskiego i Rady 2008/48/WE z dnia 23 kwietnia 2008 roku w sprawie umów o kredyt konsumencki; M. Namysłowska D. Lubasz, Ustawa o prawach konsumenta, Warszawa 2015, k. 13-19. Zob. M. Pazdan, [w:] System Prawa Prywatnego, t. 1, red. M. Safjan, Warszawa 2012, s. 1110 -1113 .

19 A. Gawrysiak-Zabłocka, Zakres zastosowania dyrektywy 2008/48/WE w sprawie umów o kredyt konsumencki, [w:] Prawo handlowe po przystapieniu Polski do Unii Europejskiej. Materiaty konferencyjne (Łódź, 23-26.09.2009), red. i wstęp W.J. Katner, U. Romińska, Warszawa 
Na podstawie ustawy z dnia 5 sierpnia 2015 roku o zmianie ustawy o nadzorze nad rynkiem finansowym oraz niektórych ustaw znowelizowano ustawę z dnia 12 maja 2011 roku o kredycie konsumenckim, wprowadzając do jej przepisów art. 36a-36d regulujące tak zwany limit pozaodsetkowych kosztów kredytu. Zgodnie z jego ust. 1 maksymalną wysokość pozaodsetkowych kosztów kredytu oblicza się według wzoru:

$M P K K \geq(K \times 25 \%)+(K \times N / R \times 30 \%)$

w którym poszczególne symbole oznaczają:

MPKK - maksymalną wysokość pozaodsetkowych kosztów kredytu,

$\mathrm{K}$ - całkowitą kwotę kredytu,

$\mathrm{N}$ - okres spłaty wyrażony w dniach,

$\mathrm{R}$ - liczbę dni w roku.

Maksymalna wysokość pozaodsetkowych kosztów została ustalona przez ustawodawcę poprzez sumę dwóch składowych wynikających z wskazanego wzoru matematycznego. Pierwsza jest wartością stałą i stanowi $25 \%$ całkowitej kwoty kredytu. Druga ma na celu skorelowanie wysokości tych kosztów do okresu spłaty. W ust. 2 ustawodawca określił pułap pozaodsetkowych kosztów kredytu, przyjmując, że w całym okresie kredytowania nie mogą być wyższe od całkowitej kwoty kredytu, czyli nie mogą przekroczyć 100\% kredytu. Z kolei w ust. 3 ustawodawca przewidział sankcję z tytułu przekroczenia limitu. W razie przekroczenia przez kredytodawcę $\mathrm{w}$ umowie kwoty pozaodsetkowych kosztów kredytu ponad limit wskazany w art. 36a na konsumencie ciąży obowiązek pokrycia tych kosztów, ale wyłącznie do kwoty odpowiadającej wartościom maksymalnym (art. 36a ust. 3). Przekroczenie zaś wartości udzielonego kredytu jest świadczeniem nienależnym wierzycielowi (art. 26a ust. 3). W art. 5 pkt 6 i 6a) wspomnianej ustawy zawarto definicje legalne całkowitego kosztu kredytu, ustawowych całkowitych kosztów kredytu, całkowitej kwoty kredytu oraz całkowitej kwoty do zapłaty. Pierwszą ustawodawca zdefiniował jako wszelkie koszty, które konsument jest zobowiązany ponieść w związku z umową o kredyt. Z kolei terminem, „pozaodsetkowe koszty kredytu” ustawodawca objął wszystkie koszty, które konsument ponosi w związku z umową o kredyt konsumencki, z wyłączeniem odsetek. Za całkowitą kwotę kredytu ustawodawca przyjął maksymalną kwotę wszystkich środków pieniężnych nieobejmujących kredytowanych kosztów kredytu, które kredytodawca udostępnia konsumentowi na podstawie umowy o kredyt konsumencki wreszcie w art. 5 ust. 1 pkt 8 sformułować pojęcie całkowitej kwoty do zapłaty przez konsumenta jako sumę całkowitego kosztu kredytu i całkowitej kwoty kredytu.

2010, s. 384-391; D. Sowińska-Kobelak, M. Gryber, Przewodnik po kredycie konsumenckim, Warszawa 2018. 


\section{Tło normatywne problemu dostrzeżone przez sąd odsyłający}

Wśród przedstawicieli doktryny panuje zgoda co do tego, że wprowadzona instytucja pozaodsetkowych kosztów kredytowych nie jest znana dyrektywie ${ }^{20}$. Przyjmuje się jednak, że wspomnianą definicję powinno się interpretować w świetle definicji całkowitego kosztu kredytu, która z kolei została zaczerpnięta z art. 3 lit. g dyrektywy 2008/48/WE ${ }^{21}$. W myśl definicji dyrektywy „całkowity koszt kredytu ponoszony przez konsumenta" oznacza wszystkie koszty łącznie z odsetkami, prowizjami, podatkami oraz wszelkimi innymi opłatami, które konsument jest zobowiązany ponieść $\mathrm{w}$ związku z umową o kredyt, które to koszty znane są kredytodawcy, z wyjątkiem kosztów notarialnych; uwzględnia się tutaj także koszty dodatkowych usług dodatkowych związanych z umową, w szczególności składki z tytułu ubezpieczenia, jeżeli zawarcie umowy dodatkowej jest niezbędne do uzyskania kredytu ${ }^{22}$. Stąd przyjmuje się w doktrynie, że pozaodsetkowe koszty kredytu powinny oznaczać wszelkie opłaty niebędące odsetkami, które konsument jest zobowiązany ponieść $\mathrm{w}$ związku $\mathrm{z}$ umową o kredyt konsumencki, a ponadto znane są kredytodawcy, a ich poniesienie jest konieczne (niezbędne) do uzyskania kredytu lub do uzyskania kredytu na oferowanych warunkach ${ }^{23}$.

Sąd odsyłający doszedł do przekonania, że skoro dyrektywa 2008/48 dokonała harmonizacji w dziedzinie pojęcia całkowitego kosztu kredytu, to właśnie kryteria desygnacyjne tej definicji winny wyznaczać możliwy zakres obciążenia finansowego kredytobiorcy na gruncie krajowego porządku prawnego. Jak już zasygnalizowano, przedmiotem zauważonych przez sąd odsyłający kontrowersji interpretacyjnych nie była jednak sama niespójność terminologiczna ustawy z dyrektywą, ale wadliwość przyjęcia przez ustawodawcę współczynników procentowych (założeń) zawartych w ustalonym przez niego wzorze, to jest kosztów operacyjnych przedsiębiorcy oraz ryzyka inwestycyjnego.

Wypada podkreślić, że jakkolwiek w polskim systemie prawnym materiały legislacyjne, w tym projekty uzasadnienia ustawy, nie stanowią źródeł prawa, niemniej jednak nie sposób zaprzeczyć, że tworzą niewątpliwą i bogatą bazę wiedzy pozwalającą poznać i uchwycić intencję przyświecającą ustawodawcy kreującemu nową instytucję prawną ${ }^{24}$. Stąd zawarte w niej kryteria mogą i powinny być pomocniczo uwzględnione przy ocenie ostatecznego efektu prac ustawodawcy, także pod kątem finalizacji uprzednio określonych w projektach zamierzeń i założeń systemowych. Na kanwie niniejszej sprawy taki modus operandi glosatora wydaje się bardziej uzasadniony, jeśli uwzględni się okoliczność, że bez odwołania się do

20 Ustawa o kredycie konsumenckim, red. M. Stanisławska, Warszawa 2018, s. 102.

21 Ibidem.

22 Ibidem.

23 Ibidem.

24 Z. Tobor, Rola materiałów legislacyjnych w porzadku prawnym, „Przegląd Prawa i Administracji” 4, 2016, s. 171-172. 
uzasadnienia projektu ustawy nie jest w zasadzie możliwe ustalenie właściwego znaczenia wzoru zamieszczanego przez ustawodawcę w art. 36a. Wynika to z faktu, że sposób i kryteria wyskalowania zamieszczonych w ustawie nowelizującej wartości procentowych (oszacowanych na poziomie odpowiednio 25\% i 30\%) ustawodawca ujawnił wyłącznie w projekcie tej ustawy (w ustawie ograniczył się jedynie do wyjaśnienia wskazanych w tym wzorze symboli).

Z lektury projektu uzasadnienia ustawy wynika, że ustawodawca wyliczył ustalone w art. 36a wartości na analizie danych dotyczących działalności finansowej reprezentatywnej rynek kredytowy grupie kredytodawców ${ }^{25}$. W wyniku ich analizy następnie ustalił, że w segmencie mikropożyczek, w którym okres kredytowania na ogół nie przekracza miesiąca, koszty operacyjne kształtują się na poziomie 15-27\% kwoty pożyczki. Do kosztów operacyjnych ustawodawca postanowił dodać koszt ryzyka, w segmencie mikropożyczek oscylujący w granicach 11\% (odsetek pożyczek straconych), stąd przeciętne koszty stałe kredytodawcy oszacował on w przedziale 26-38\% całkowitej kwoty kredytu. W takim stanie rzeczy ustawodawca przyjął, że limit pozaodsetkowych kosztów kredytu w wysokości 25\% całkowitej kwoty kredytu (pierwsza wartość przewidziana we wzorze w art. 36a ust. 1 KredytKonsU) odpowiada zatem dolnej granicy kosztów stałych ponoszonych rzeczywiście przez kredytodawców, co ma ich motywować do racjonalizacji tych kosztów z korzyścią dla konsumenta. W uzasadnieniu jasno wskazano też, że limit ten, jako stały, ma być niezależny od okresu kredytowania, a jego celem jest umożliwienie przedsiębiorcom pokrycia kosztów stałych związanych z udzieleniem pożyczki. Z kolei koszty operacyjne w segmencie pożyczek udzielanych na dłuższe okresy ustawodawca ustalił na 27,5-51\% kwoty pożyczki. Podobnie jak poprzednio do kosztów operacyjnych dodał koszt ryzyka, 22-25\%. Finalizując wyliczenia, ustawodawca doszedł do wniosku, że całkowite koszty pożyczki udzielonej na okres około jednego roku będą oscylować w granicach 49,5-76\% kwoty pożyczki, a z kolei maksymalny koszt kredytu w skali jednego roku nie będzie mógł przekroczyć 55\% kwoty kredytu $(25+30 \%)$, a w skali sześciu miesięcy 40\% $(25+15 \%)$.

Jednocześnie zauważono, że przedsiębiorca udzielający pożyczki na dłuższy okres powinien czerpać swoje wynagrodzenie z oprocentowania pożyczki, nato-

25 Limit całkowitego kosztu kredytu z wyłączeniem odsetek został przygotowany na podstawie analizy dostępnych danych dotyczących działalności „firm pożyczkowych”: „Rynek firm pożyczkowych w Polsce" — raport PwC sp. z o.o. z grudnia 2013 roku, Mikropożyczki w Polsce - raport Związku Firm Pożyczkowych przygotowany pod kierunkiem dr. Łukasza Gębskiego w 2013 roku, Rynek firm pożyczkowych w Polsce. Charakterystyka sektora i profil klienta raport Konferencji Przedsiębiorstw Finansowych przygotowany przez dr. Piotra Białowolskiego w sierpniu 2012 roku, Wptyw regulacji sektora finansowego w postaci maksymalnej stopy procentowej na rynek finansowy i gospodarke - ocena ekspercka na podstawie modeli oceny ryzyka — raport Konferencji Przedsiębiorstw Finansowych przygotowany przez dr. Piotra Białowolskiego w październiku 2013 roku, opracowania i analizy przekazane przez partnerów społecznych. 
miast pozostałe koszty narzucone na kredytobiorcę powinny odzwierciedlać realne koszty ponoszone przez przedsiębiorcę. Również w uzasadnieniu projektu wskazano na ratio legis wprowadzenia tej regulacji. Podkreślono okoliczność, że ograniczenia możliwości pobierania nadmiernych odsetek wynikających z art. $359 \S 2^{1} \mathrm{kc}$ nie stanowi wystarczającego instrumentu ochrony interesów konsumenta w sytuacji, gdy przedsiębiorcy, przestrzegając regulacji dotyczących maksymalnej wysokości odsetek, jednocześnie zastrzegają wysokie prowizje i dodatkowe opłaty o charakterze pozaodsetkowym. W konsekwencji tego rodzaju praktyk łączne koszty obsługi długu niejednokrotnie przekraczają wysokość zaciągniętej pożyczki lub kredytu. Wysokie koszty pozaodsetkowe, w przypadku korzystania przez konsumenta z pożyczek i kredytów w kilku instytucjach jednocześnie, powodują szybko rosnący obszar zadłużenia. [...] celem jest zapobieganie przypadkom pobierania przez kredytodawców kredytu konsumenckiego nieuzasadnionych (zbyt wysokich) opłat. Przepis ten miał także zapobiegać obchodzeniu przepisów o odsetkach maksymalnych, w szczególności poprzez zastrzeganie na rzecz kredytodawcy różnego rodzaju wygórowanych opłat i prowizji. Również w doktrynie pozostaje poza sporem, że intencją ustawodawcy nowelizującego ustawę była ochrona konsumentów przed nadmiernym obciążeniem finansowym w związku z kredytem konsumenckim (lichwą) ${ }^{26}$.

\section{Wnioski końcowe}

W świetle uzasadnienia ustawy nowelizacyjnej nie ulega wątpliwości, że legislator faktycznie w sposób zawoalowany i arbitralny wprowadził do kosztów związanych z udzieleniem pożyczki czy kredytu również koszty prowadzenia działalności gospodarczej przez przedsiębiorcę udzielającego kredytu lub pożyczki ${ }^{27}$, przyznając możliwość zwiększenia obciążenia finansowego konsumenta poza granice desygnatów wyznaczonych przez instytucję całkowitych kosztów kredytu, to jest kosztów związanych z umową. Nie dość, że po wejściu w życie normy art. 36a KredytKonsU wysokie opłaty (prowizje itp.) uzyskały ustawową delegację (podczas gdy przed reformą ustawodawczą w analogicznie ustalanych wysokościach opłaty były traktowane jako wygórowane i niesprawiedliwe ${ }^{28}$ ), to dodatkowo, na co wskazał sąd odsyłający, w samym limicie pozaodsetkowych kosztów kredytowych wprowadzono drugi element niezwiązany z konkretnym kredytem, którego koszt nie jest znany kredytodawcy, to jest ryzyko przedsiębiorcy. Wprowadzono zatem w ramach limitu maksymalnych kosztów kredytu quasi-prowizję

26 Uzasadnienie projektu ustawy, VII kadencja, druk sejmowy, nr 3460, www.sejm.gov.pl. Zob. T. Czech, Kredyt konsumencki. Komentarz, Warszawa 2018, s. 400.

27 Pojęcie „koszty działalności operacyjnej” istnieje w ustawie o rachunkowości, w której operuje się pojęciem kosztów działalności operacyjnej i za które uznaje się koszty ponoszone w związku podstawową działalnością jednostki; zob. K. Czubawska, aktual. T. Kiziukiewicz, M. Janowicz, [w:] Ustawa o rachunkowości. Komentarz, red. T. Kiziukiewicz, Warszawa 2016, s. 379-380.

28 Por. uzasadnienie wyroku Sądu Okręgowego w Poznaniu z dnia 13 kwietnia 2017 roku, II Ca 286/17, w którym SO uznał, że opłata wynosząca ponad 50\% kwoty wypłaconej pożyczkobiorcy w ramach pożyczki udzielonej na okres 40 tygodni nie jest sprawiedliwym wynagrodzeniem dla pożyczkodawcy, podczas gdy pozaodsetkowe koszty kredytu w skali 6 miesięcy osiągają $40 \%$, a w skali roku 55\% całkowitej kwoty kredytu. 
od ryzyka inwestycyjnego, co intuicyjnie budzi obiekcje. Powszechnie przyjmuje się bowiem, że prowadzenie działalności gospodarczej nierozerwalnie wiąże się z ryzykiem i jest relewantnie sprzężonym z nim elementem gry rynkowej. To właśnie przedsiębiorca w ramach czynności racjonalizatorskich powinien podejmować takie działania, które skoncentrowane są na obniżeniu stopnia ryzyka i jego wpływu na działanie firmy. Same zaś straty firmy mogą wynikać z niewłaściwej strategii inwestycyjnej pożyczkodawcy, nierentownych decyzji (udzielanie pożyczek osobom pozbawionym zdolności kredytowej) itp. Rekompensata strat firmy przez wprowadzenie swoistej prowizji od ryzyka obciążającej wszystkich kredytodawców jest więc pewnego rodzaju ingerencją ustawodawcy w zasady wolnego rynku. Powołany do życia w tym zakresie nowelizacją model przewiduje bowiem zbiorową odpowiedzialność wszystkich kredytobiorców za ryzyko strat firmy pożyczkowej. W aktualnym stanie prawnym oznacza to, że każdy kredytobiorca, i to bez względu na to, czy należy do grupy klienta potencjalnie niewypłacalnego, to jest generującego straty firmy pożyczkodawcy, czy też jest jego lojalnym klientem, de facto ponosi finansowe obciążenie za ryzyko negatywnych skutków kapitałowych po stronie kredytodawcy — bez względu na przyczynę ich powstania ${ }^{29}$. Nie można jednak stracić z pola widzenia okoliczności, że jak wynika z uzasadnienia ustawodawcy krajowego, wyrażony w art. 36a wzór chroni zaledwie dolne granice kosztów ponoszonych przez przedsiębiorcę udzielającego kredytu konsumenckiego. Mimo że powołany przepis ma charakter semidyspozytywny ${ }^{30}$, to jednak racjonalność ekonomiczną pozostania przy wysokościach maksymalnych pozaodsetkowych kosztów sugeruje ekonomiczna ocena rentowności pracodawcy dokonana przez ustawodawcę ${ }^{31}$.

Wreszcie sąd odsyłający zauważa, że skutkiem wprowadzenia limitów pozaodsetkowych kosztów kredytowych do porządku krajowego jest też radykalne zmniejszenie możliwości oceny postanowień umów pod kątem ich abuzywności czy nieważności ze względu na sprzeczność z przepisami prawa, działaniem w celu obejścia prawa czy sprzeczność z zasadami współżycia społecznego. Skłania to zatem do oczywistej refleksji, czy wprowadzony model funkcjonowania instytucji pozaodsetkowych kosztów kredytu naprawdę spełnia założenia ochrony konsumenta przed nadmiernym obciążeniem finansowym w związku z kredytem konsumenckim, a w konsekwencji podaje w wątpliwość zgodność rozwiązań zastosowanych w prawie polskim z dyrektywą 2008/48/WE. Taki wniosek wydaje

29 W przypadku przedsiębiorców prowadzących działalność gospodarczą na rynku kredytowym mogą to być straty wynikające z opieszałości przy dochodzeniu wierzytelności i tym samym skutkujące przedawnieniem roszczenia, oddalenia powództwa z powodu naruszenia reguł dowodowych względnie wprowadzenia do umowy postanowień ocenionych jako klauzule abuzywne itp.

30 Zob. T. Czech, Kredyt konsumencki..., s. 401 „mogą zostać zmienione jedynie na korzyść konsumenta".

31 Zob. uzasadnienie pytania prejudycjalnego - Postanowienie Sądu Rejonowego w Siemianowicach Ślaskich z dnia 9 listopada 2018 roku sygn. akt I C 2923/17. 
się tym bardziej zasadny, jeśli weźmie się pod uwagę okoliczność, że ów brak referencji krajowych rozwiązań ustawowych do wspomnianych norm unijnych dostrzegły także inne sądy krajowe, występując z kolejnymi pytaniami prejudycjalnymi, co dodatkowo sygnalizuje wadliwość przyjętej przez ustawodawcę regulacji ustawowej ${ }^{32}$. Wypada przy tym podkreślić, że wstąpienie Rzeczypospolitej Polskiej do Unii Europejskiej nie tylko nałożyło na sądy obowiązek stosowania prawa unijnego, ale także spowodowało objęcie procesu stosowania tego prawa kontrolą organów wspólnotowych. Bezsprzecznie w ramach środków kontrolnych szczególne znaczenie stanowią udzielane przez TSUE odpowiedzi na pytania prejudycjalne sądów krajowych ${ }^{33}$.

Bez wątpienia główną rolą TSUE będzie wytyczenie linii demarkacyjnej obszaru materii podlegającej harmonizacji ${ }^{34}$. Należy jednak zauważyć, że Trybunał wielokrotnie przypominał o spoczywającym na sądzie krajowym obowiązku przystąpienia do badania z urzędu naruszenia niektórych przepisów prawa Unii obowiązujących w dziedzinie ochrony konsumenta ${ }^{35}$. Jak reglamentował w swych orzeczeniach, w celu zapewnienia ochrony zamierzonej przez dyrektywę nierównowaga między konsumentem a przedsiębiorcą może zostać zniesiona jedynie czynną interwencją sądu krajowego ${ }^{36}$. Jest to oczywiście konsekwencją przyję-

32 Rzeczone wyżej pytania prejudycjalne Sądu Rejonowego w Siemianowicach Śląskich sygn. akt I C-779/18 oraz Sądu Rejonowego Szczecin — Prawobrzeże i Zachód w Szczecinie I C 84-/19.

${ }^{33}$ Zob. A. Zieliński, [w:] System Prawa Prywatnego, red. Z. Radwański, t. 2, Warszawa 2019, s. $905-906$.

${ }^{34}$ Zob. T. Czech, Kredyt konsumencki..., s. 400: „Art. 36a-36d nie implementują żadnej reguły wynikającej z dyrektywy Europejskiej [...] zagadnienie (normatywnej ochrony konsumentów przed lichwą przyp. autor) nie jest objęte zasadą harmonizacji zupełnej, o której mowa w art. 22 ust. 1 dyrektywy 2008/48, ponieważ dyrektywa ta nie zawiera regulacji dotyczących zwalczania lichwy".

35 Zob. podobnie, w odniesieniu do dyrektywy 93/13, wyrok: z dnia 27 czerwca 2000 roku w sprawach połączonych: od C-240/98 do C-244/98, Océano Grupo Editorial SA v. Roció Murciano Quintero (C-240/98) i Salvat Editores SA v. José M. Sánchez Alcón Prades (C-241/98), José Luis Copano Badillo (C-242/98), Mohammed Berroane (C-243/98) i Emilio Viñas Feliú (C-244/98) ECLI:EU:C:2000:346 pkt 27; z dnia 26 października 2006 roku w sprawie C-168/05 w sprawie Mostaza Claro, ECLI:EU:C:2006:675 pkt 26; z dnia 6 października 2009 roku w sprawie C-40/08 w sprawie Asturcom Telecomunicaciones, ECLI:EU:C:2009:615 pkt 31; z dnia 9 listopada 2010 roku w sprawie C 137/08 VB Pénzügyi Lízing, ECLI:EU:C:2010:659 pkt 48); z dnia 13 września 2018 roku sprawie C 176/17 w sprawie Profi Credit Polska, ECLI:EU:C:2018:293 pkt 42.

36 Zob. podobnie, w odniesieniu do dyrektywy 93/13, wyrok: z dnia 27 czerwca 2000 roku w sprawach połączonych: od C-240/98 do C-244/98, Océano Grupo Editorial SA v. Roció Murciano Quintero (C-240/98) i Salvat Editores SA v. José M. Sánchez Alcón Prades (C-241/98), José Luis Copano Badillo (C-242/98), Mohammed Berroane (C-243/98) i Emilio Viñas Feliú (C-244/98) ECLI:EU:C:2000:346 pkt 27; z dnia 26 października 2006 roku w sprawie C-168/05 w sprawie Mostaza Claro, ECLI:EU:C:2006:675 pkt 26; z dnia 6 października 2009 roku w sprawie C-40/08 w sprawie Asturcom Telecomunicaciones, ECLI:EU:C:2009:615 pkt 31; z dnia 9 listopada 2010 roku w sprawie C 137/08 VB Pénzügyi Lízing, ECLI:EU:C:2010:659 pkt 48); z dnia 13 września 2018 roku sprawie C 176/17 w sprawie Profi Credit Polska, ECLI:EU:C:2018:293 pkt 42.

Studenckie Prace Prawnicze, Administratywistyczne

i Ekonomiczne 30, 2019

(C) for this edition by CNS 
tego uznania konsumenta za stronę słabszą niż przedsiębiorca ${ }^{37}$. Ponadto TSUE wielokrotnie podkreślał, że sąd krajowy — będący zatem zobowiązany do zapewnienia skuteczności (effet utile) ochrony konsumentów, której zagwarantowanie jest celem przepisów dyrektywy 2008/48 - pełni w rozpatrywanej dziedzinie przyznaną mu przez prawo Unii funkcję, która nie ogranicza się do zwykłej możliwości orzeczenia w przedmiocie poszanowania owych wymogów, ale obejmuje także obowiązek zbadania tej kwestii z urzędu, gdy tylko sąd krajowy dysponuje niezbędnymi w tym celu informacjami na temat okoliczności prawnych i faktycznych $^{38}$. Z kolei na płaszczyźnie rozważanej problematyki swoisty drogowskaz interpretacyjny może stanowić powołany przez sąd odsyłający wyrok TSUE z 16 stycznia 2014 roku, C-226/12 ${ }^{39}$, w którym Trybunał zakwestionował dopuszczalność przerzucenia na konsumenta obowiązku zapłaty podatku od wartości obciążającego przedsiębiorcę i wskazał, że taki stan może zostać zakwalifikowany jako odpowiadający pojęciu ,znaczącej nierównowagi” w rozumieniu art. 3 ust. 1 dyrektywy Rady 93/13/EWG z dnia 5 kwietnia 1993 roku w sprawie nieuczciwych warunków w umowach konsumenckich ${ }^{40}$.

\section{Podsumowanie}

W salach sądowych toczy się żywy dyskurs prawniczy, w którym ścierają się dwie przeciwstawne koncepcje prawne, mające swoich zwolenników i silne uzasadnienie $\mathrm{w}$ argumentacji prawniczej. Jednocześnie dokonania przedstawicieli doktryny wypracowane dotychczas na tym polu ogniskują się wokół komentowania rozwiązań systemowych przyjętych przez ustawodawcę $e^{41}$ i nie podejmują problemów podno-

37 Wyroki z dnia 27 czerwca 2000 roku w sprawach połączonych w sprawach połączonych: od C-240/98 do C-244/98, Océano Grupo Editorial SA v. Roció Murciano Quintero (C-240/98) i Salvat Editores SA v. José M. Sánchez Alcón Prades (C-241/98), José Luis Copano Badillo (C-242/98), Mohammed Berroane (C-243/98) i Emilio Viñas Feliú (C-244/98) ECLI:EU:C:2000:346 pkt 25; z dnia 26 października 2006 roku w sprawie C-168/05 Mostaza Claro ECLI:EU:C:2006:675, pkt 25; oraz z dnia 6 października 2009 roku w sprawie C-40/08 Asturcom Telecomunicaciones, ECLI:EU:C:2009:615 pkt 29).

38 Wyrok z dnia 4 czerwca 2009 roku, Pannon GSM, C-243/08, EU:C:2009:350, pkt 32.

39 Wyrok z dnia 16 stycznia 2014 roku, Constructora Principado SA przeciwko Josému Ignaciowi Menéndezowi Álvarezowi, C-226/12, ECLI:EU:C:2014:10.

40 Trybunał orzekł w powołanym judykacie, że aby istniała „znacząca nierównowaga”, nie jest konieczne, by koszty obciążające konsumenta na mocy postanowienia umownego miały względem niego istotny ekonomiczny wpływ w świetle kwoty danej transakcji, lecz nierównowaga ta może wynikać z samego faktu wystarczająco poważnego naruszenia sytuacji prawnej, w której konsument, jako strona danej umowy, znajduje się na mocy właściwych przepisów krajowych, czy to w postaci ograniczenia treści praw, które zgodnie z rzeczonymi przepisami przysługują mu na podstawie tej umowy, czy to przeszkody w ich wykonywaniu, czy też nałożenia na niego dodatkowego obowiązku, którego nie przewidują normy krajowe.

41 Zob. P. Mikłaszewicz, [w:] Komentarze prawa prywatnego, t. 7, red. K. Osajda, Warszawa 2019, s. 514-515; Ustawa o kredycie..., s. 102-104; T. Czech, Kredyt konsumencki..., s. 399-405. 
szonych od pewnego czasu w judykaturze, co dodatkowo uniemożliwia realizację dążeń do osiągnięcia zasady pewności prawa w tym zakresie. Jest to zapewne wynikiem powolnego procesu krystalizowania się problemów wynikających z powołanej stosunkowo niedawno do życia przez ustawodawcę instytucji pozakodeksowych kosztów kredytowych oraz wtórnego diagnozowania ich natury przez krajową judykaturę. Nie powinno jednak budzić wątpliwości, że gwarantem należytego uregulowania tak istotnych i newralgicznych z punktu widzenia rynku finansowego kwestii związanych z udzielaniem pożyczek konsumenckich jest sam ustawodawca, który winien zachować szczególną ostrożność na tym polu i dążyć do formułowania takich figur prawnych, które będą przejrzyste, precyzyjne, a przede wszystkim będą znajdowały oparcie w postulowanym przez unijnego ustawodawcę kanonie normatywnym. Słuszne zatem jest przyjęcie, że ewentualne wydanie judykatu przez TSUE będzie miało podstawowy wpływ na kształtowanie się jednolitej linii orzeczniczej sądów krajowych w kontekście realizacji unijnych przepisów o ochronie praw konsumenta. Jeżeli Trybunał podzieli stanowisko sądu odsyłającego i zakwestionuje wprowadzone zmiany, otworzy to nowy rozdział w kwestii przepisów krajowych w aspekcie oceny ich zgodności z prawem europejskim, stając się punktem odniesienia w sprawach o podobnym stanie faktycznym, w których czynnikiem scalającym proces sądowej subsumcji będzie uregulowana prawem krajowym sytuacja prawna konsumenta wobec przedsiębiorcy.

\section{Bibliografia}

Burczak K., Dębiński A. Jońca M., Łacińskie sentencje i powiedzenia prawnicze, Warszawa 2018.

Czech T., Kredyt konsumencki. Komentarz, Warszawa 2018.

Czubawska K., aktual. T. Kiziukiewicz, M. Janowicz, [w:] Ustawa o rachunkowości. Komentarz, red. T. Kiziukiewicz, Warszawa 2016.

Gawrysiak-Zabłocka A., Zakres zastosowania dyrektywy 2008/48/WE w sprawie umów o kredyt konsumencki, [w:] Prawo handlowe po przystapieniu Polski do Unii Europejskiej. Materiaty konferencyjne (Łódź, 23-26.09.2009), red. i wstęp W.J. Katner, U. Romińska, Warszawa 2010.

Kamiński M.T., Limit pozaodsetkowych kosztów w umowie kredytu konsumenckiego, a dopuszczalność badania abuzywności postanowień umownych $w$ tym zakresie, LEX/El 2018.

Mikłaszewicz P., [w:] Komentarze prawa prywatnego, t. 7, red. K. Osajda, Warszawa 2019.

Namysłowska M., Lubasz D., Ustawa o prawach konsumenta, Warszawa 2015.

Ofiarski Z., Ustawa o kredycie konsumenckim, komentarz, Warszawa 2014.

Pazdan M., System Prawa Prywatnego, t. 1, red. M. Safjan, Warszawa 2012.

Sowińska-Kobelak D., Gryber M., Przewodnik po kredycie konsumenckim, Warszawa 2018.

Stanisławska M., Ustawa o kredycie konsumenckim, Warszawa 2018.

Tobor Z., Rola materiatów legislacyjnych w porządku prawnym, „Przegląd Prawa i Administracji” 4, 2016.

Założenia do ustawy o kredycie konsumenckim $w$ związu z implementacja dyrektywy parlamentu Europejskiego i Rady 2008/48/WE z dnia 23 kwietnia 2008 r. w sprawie umów o kredyt konsumencki, Warszawa 2009.

Zieliński A., [w:] System Prawa Prywatnego, red. Z. Radwański, t. 2, Warszawa 2019. 